Remeikiene, R., \& Gaspareniene, L. (2021). Nexus between unemployment and the shadow economy in Lithuanian regions during the COVID-19 pandemic.

\title{
The nexus between unemployment and the shadow economy in Lithuanian regions during the COVID-19 pandemic
}

\author{
Rita Remeikiene \\ Public Safety Academy, Mykolas Romeris University, \\ Lithuania \\ rita.remeikiene@mruni.eu \\ ORCID 0000-0002-3369-485X \\ Ligita Gaspareniene \\ Public Safety Academy, Mykolas Romeris University, \\ Lithuania \\ ligitagaspareniene@mruni.eu \\ ORCID 0000-0002-5535-6552
}

\begin{abstract}
Under the current extreme conditions, with an increasing number of the unemployed, the size of the shadow economy is also growing. The competitiveness of municipalities depends to a large extent on their ability to manage unemployment and reduce the size of the shadow economy. A strategy selected for improving the municipal economy significantly affects the establishment and development of business. The article aims to assess the extent to which the unemployed are involved in the informal activities in Lithuanian regions during the COVID-19 pandemic. The research is based on the method of a representative quantitative survey. The research has revealed that the main critical issues are hiding income, work in the shadow labour market and "envelope" wages, while the major areas of shadow activities cover healthcare services, hairdressing and childcare. The research has also disclosed that the unemployed not only participate in the shadow labour market, but also justify income hiding and consumption of smuggled goods. The measures recommended for reducing the number of the unemployed are raising the average wage, exempting business start-ups from taxes for several years, and reducing the unemployment and other social benefits with consideration of one's health condition.
\end{abstract}

Keywords: unemployment, shadow economy, labour market, Lithuanian municipalities, representative quantitative survey.

JEL Classification: E24, E26, R23, O17 


\section{INTRODUCTION}

Although the shadow economy is observed in all the countries and sectors with regulated and taxed economic activities, its size may differ significantly (Navickas et. al, 2020). When unemployment rates are high, the informal sector of the economy often becomes the sector where the unemployed can earn some income, thus mitigating the destructive effects of unemployment. As noted by Burger and Fourie (2019), remuneration for work in the informal sector is commonly lower than that in the formal sector, though the former also requires significantly lower skills than the latter.

According to Nygaard and Dreyer (2020), those working in the informal sector are twice as likely to belong to poor households. Not possessing any alternative sources of income and not being protected by social security measures (because undeclared activities are not subject to taxation), individuals working in the informal sector are particularly vulnerable in the current context of the COVID-19 pandemic (Dementiev, 2021). The COVID-19 pandemic has significantly affected European and non-European enterprises (e.g., Carrasco Sierra et al., 2020; Machová et al., 2021; Simionescu, 2021 and many others). Millions of enterprises have lost their planned revenues, and millions of work positions have been compromised (Cepel et al., 2020). The International Labour Organisation estimates, provided by Nygaard and Dreyer (2020), indicate that 1.6 billion of approximately 2 billion workers operating in the informal sector of the economy worldwide will experience an average of about a $60 \%$ income decline in their current income as a result of the COVID-19 pandemic. This problem is especially topical in Ukraine. Prior to the pandemic, the shadow economy in Ukraine accounted for nearly $28 \%$ of GDP. Based on these data, the authors presume that the post-pandemic situation will be totally worse. In Ukraine it is impossible to ensure the effective development of entrepreneurship and a sufficient level of employment due to the high level of shadow business in the labor market (Melnyk et al., 2021a). In Ukraine, even in the insurance sector, the level of shadowing (provision of tax optimization services for business; use of internal incoming reinsurance to reduce tax liabilities; withdrawal of funds outside Ukraine or cash transfer using technical securities) is very high and increases every year (Melnyk et al., 2021b). The situation is no better in the banking sector, which is used for money laundering (Bukhtiarova et al., 2020). And this is the picture we have in most countries, especially in those with low incomes.

To diminish the share of the economically vulnerable individuals, it is relevant to take a deeper look at the aspects and extent of involvement of the unemployed in the shadow economy so that, based on the research results, the guidelines for reducing the scope of this phenomenon could be developed. Previous studies mainly focused on the macroeconomic context of informal employment (Hvidtfeldt et al., 2011; Schneider, 2011; Schneider et al., 2015; Burger, Fourie, 2019; Hendrickx, 2019, etc.) or analysed informal employment in particular population groups (e.g. the youth - Tefera \& Delbiso, 2013; Okeleke \& Aponjolosun, 2020; Altbeker \& Storme, 2013, etc.; women's - Pasternak-Malicka, Migała-Warchoł, 2018; rural population - Reimer, 2000; Reimer, Bollmann, 2009; Weng, 2015, etc.), while this study concentrates on the regional dimension.

The main purpose of the research is to identify the major forms of involvement of the unemployed in the shadow economy, to evaluate the extent of this phenomenon, and to develop the guidelines for reducing the number of the unemployed in the shadow economy. The defined purpose was detailed into the following objectives: 1) based on literature analysis, to provide the factors limiting the potential of the unemployed in the formal labour market; 2) to classify and review the most common forms of participation of the unemployed in the shadow economy; 3) to select and substantiate the methodology of the research; 4) based on the results of the empirical research, to identify the most common forms of involvement of the unemployed in the shadow economy in Lithuanian regions. 
Novelty of the research. Novelty of the research lies in assessment of involvement of the unemployed in the informal labour market and consumption of smuggled goods. Given that during the pandemic, the unemployed are facing the difficulties to find a job, the research examines the (in)tolerance of the unemployed to the shadow economy.

The research methods include comparative and systematic literature analysis and a representative survey of the unemployed.

\section{LITERATURE REVIEW}

\subsection{Factors limiting the potential of the unemployed in the formal labour market}

The labour market establishes the relations between the supply (employees) and demand (employers) for labour. The total labour supply depends on at least four factors: the number of inhabitants, the share of workers in the total population, the average number of working hours per week or year, and the quality, quantity and qualification of work. The labour market is an important segment of any economy. It is related to the capital market, the market of goods and services, and various economic entities (governments, companies and households) (Draskovic et al., 2021). Some studies (National Planning Commission 2012; Schneider et al., 2015) indicate that the activities of the unemployed in the informal economy are a natural part of an economic cycle because namely the informal sector absorbs surplus labour from the formal sector during the period of an economic downturn. A high unemployment rate inherent to the latter promotes the development of the shadow economy because the unemployed tend to engage in shadow activities so as not to lose state-paid unemployment benefits, but at the same time seek alternative sources of income. The close relationship between the shadow economy and the labour market was confirmed by Perry et al. (2007), Fialova (2010), Pocius (2015) and many other authors. Nevertheless, Rogan and Skinner's (2017), Burger and Fourie's (2019) and some other studies do not confirm the role of the informal sector in absorbing surplus labour. On the contrary, the above-mentioned studies show that even when the unemployment rate is rising during the period of an economic downturn or shock, transfer to the informal sector is not such a simple solution, since there exist particular barriers for entities to enter the informal sector. According to Grimm et al. (2011), individuals wishing to enter the informal sector may face barriers, such as a lack of skills or capital. There are also cases when an employee continues working in the usual workplace, but an employer starts paying the "envelope" wages. This means that an employee possesses sufficient skills and capital, but an employer just wants to save on taxes.

Tefera and Delbiso (2013) additionally point to the barriers such as lack of working premises, an adequate market and raw materials. Due to the effects of the above-mentioned barriers, the informal sector does not act as a full downturn or shock absorber, i.e., a sector in which all the unemployed are able to find an occupation. At best, it acts only as a partial absorber (Burger and Fourie, 2019), which means that involvement of the unemployed in the shadow economy is determined not by pure economic cycles, but by a complex of various factors that limit the potential of the unemployed to find a job, and the decline in the number of work places in the formal economy during its downturn is only one of these factors. As it was noted by Fialova (2010), economic agents may not enter the labour market either due to the lack of opportunities or may leave the formal sector voluntarily for monetary or non-monetary benefits.

A lack of education and skills is considered to be a significant obstacle for the unemployed to find formal employment (Krisnaresanti et al., 2020). According to the statistics from Altbeker and Storme (2013), the unemployment rate for early school leavers is as high as 50\%. Kolm and Larsen (2016) state 
that informal work opportunities for manual workers or workers with low education are substantially higher than for those with higher education, especially in regions.

The modern knowledge-based economy, technological advancement and globalization require a constant increase in the level of knowledge, but being characterized by reduced mobility, regional (rural) residents cannot improve or have no motivation for improvement (Fernando, 2020). As noted by Gadsby and Samson (2016), rural communities do not even have a so-called 'learning culture'. According to Reimer and Bollman (2009), residents of rural areas are not motivated to pursue knowledge and education because having an access to only low-skilled jobs and facing the problems of a process complexity and high risks when trying the establish a business, they feel their efforts to raise skill levels will be wasted, and they will incur costs that will not pay off later.

Based on the previously mentioned studies by Gadsby and Samson (2016), and Reimer and Bollman (2009), a relationship between agents' participation in the shadow economy and the place of residence can be envisaged: it was found that rural residents face more difficulties in finding a job than urban residents because with significantly lower investment flows (Ramasamy et al., 2017; Li et al., 2018) and a lack of infrastructure (Gadsby \& Samson, 2016), regional residents are likely to face such relevant problems as a lack of attractive work places or work places in general (Williams, 2011), wage inequalities (Liu et al., 2011), etc. With reference to Weng (2015), the informal economy in rural areas is a source of livelihood for the poor, when the latter exploit natural resources (primarily land) to conduct economic activities, such as farming, timber production, etc.

On the other hand, Tefera and Delbiso's (2013) survey-based study revealed that as many as $90 \%$ of the people working in the informal sector do so not because of low education or place of residence, but because of the improvement of their standard of living. In contrast to the above-mentioned studies, Tefera and Delbiso (2013) found that either higher education or city residence do not hinder agents' involvement in the informal sector due to wider opportunities to find a formal job, but, on the contrary, even provide them with higher profits and a longer stay in the informal sector.

Literature analysis also disclosed the economic sectors with the highest levels of informal unemployment. Based on Hvidtfeldt et al.'s (2011) research in the Danish economy and Haigner et al.'s (2011) research in the German economy, the highest level of informal work is characteristic of the construction sector, which is followed by the agricultural sector and the hotels and restaurants sector. The lowest levels of informal work in these countries are observed in the industrial sector.

Summarising, literature analysis suggests that the key factors limiting the potential of the unemployed to find a job in the formal sector and thus pushing them to operate in 'the shadow' are a smaller number of work places in the formal economy during the periods of its downturn or shock, a lack of education and skills, and rural residence with lower infrastructure and mobility opportunities. Nevertheless, these factors cannot be considered absolute because they determine agents' decision to operate in the informal sector only insofar as this operation can raise their income and improve the standard of living.

\subsection{Forms of participation of the unemployed in the shadow economy}

In a general sense, the shadow labour market is referred to as "all cases, where the employees or the employers, or both, occupy a shadow economy position" (Schneider, 2011, p. 21). The OECD Development Centre provides a narrower, but more detailed definition of informal employment which is treated as "working arrangements that are de facto or de jure not subject to national labour legislation, income taxation or entitlement to social protection or certain other employment benefits (advance notice of dismissal, severance pay, paid annual or sick leave, etc.)." (OECD Development Centre, 2019, p. 26). 
Both the broader and narrower interpretations of informal employment (or the informal labour market) suggest that informal unemployment may manifest in many different forms. Most common forms of participation of the unemployed in the shadow economy, identified on the basis of literature analysis, can be attributed to two main categories (see Table 1).

Table 1

Categorization of the forms of participation of the unemployed in the shadow economy

\begin{tabular}{|l|l|l|}
\hline Categories & Forms & Author(s), year \\
\hline $\begin{array}{l}\text { By the degree of } \\
\text { (non)formalization }\end{array}$ & $\begin{array}{l}\text { Informal work with regular employment } \\
\text { contracts, informal work with regular part-time } \\
\text { employment contracts, self-employment, small } \\
\text { enterprises, fully informal work, Local } \\
\text { Exchange Trading Systems }\end{array}$ & $\begin{array}{l}\text { Williams, 1996; Schneider, 2011; } \\
\text { Pacolet, De Wispelaere, 2013; } \\
\text { Shand, Heyes, 2017; OECD } \\
\text { Development Centre, 2019; WIEGO, } \\
2020\end{array}$ \\
\hline By the activity spaces & $\begin{array}{l}\text { Informal work in public spaces, informal work } \\
\text { at home, informal work in agriculture, } \\
\text { informal work in other spaces }\end{array}$ & $\begin{array}{l}\text { Medina, 2008; Walsh, 2010; Weng, } \\
\text { al., 2017; Shapland, Heyes, 2017; } \\
\text { Truong, 2018; Hendrickx, 2019; } \\
\text { OECD Development Centre, 2019; } \\
\text { WIEGO, 2020 }\end{array}$ \\
\hline
\end{tabular}

Source: compiled by the authors

When analysing the forms of participation of the unemployed in the shadow economy, categorized by the degree of (non)formalisation, it should be noted that a wide range of variations, starting with regular employment contracts and ending with involvement in the so-called Local Exchange Trading Systems, is possible. Individuals who have regular employment contracts can informally work outside regular working hours, get involved in informal work at weekends, etc. Similar principles apply to informal work performed by individuals with regular part-time employment contracts. Schneider (2011) indicates that a large part of informal workers are self-employed, some of them owe and manage very small enterprises. Finally, this category covers fully informal activities that can be conducted by one person, a group of related persons or a family. According to the OECD Development Centre's (2019) estimations, of the total number of the individuals operating in the informal sector, $67.4 \%$ work in informal sector units, $27.3 \%$ work in fully formal enterprises, and $5.3 \%$ are domestic workers. Self-employed individuals represent the majority of informal workers (45\%), followed by employees $(36 \%)$, contributing family workers (16\%) and employers (below 3\%). Williams's (1996) research shows that the unemployed can participate in the informal sector of the economy through informal exchanges, called Local Exchange Trading Systems (LETS). The essence of these systems is that participants (especially at the community level) exchange goods and services without using money as an exchange intermediary. For this purpose, participating individuals create certain groups - associations, within which they exchange goods and services. In this way, the unemployed are trying to solve the cash shortage problem.

In the category of informal work by activity spaces, operation in public spaces, at home, in agriculture and other spaces can be highlighted. The agents informally operating in public spaces are often involved in street vending (Walsh, 2010; Martinez et al., 2017; Truong, 2018; CGAP, 2020; WIEGO, 2020, etc.): they sell a wide range of goods from foodstuff (fruit, vegetables, bakery, meat, beverages, prepared foods Vasylieva, 2021), garment and crafts, domestic appliances, etc. According to Truong (2018), in developing countries, the determinants of street vending lie in low farm output, limited farming land, declined nonfarm jobs, and other family-related situations. WIEGO's (2020) report also indicates that a substantial share of informal workers operating in public spaces are found in the transport sector - taxi drivers, cart pullers, bicycle peddlers, rickshaw pullers, etc. The category of the individuals informally working in public 
spaces also covers waste pickers - individuals who collect waste (i.e., what others have thrown away) and earn money by taking this waste to reverse vending machines, recycle centres, etc. (Medina, 2008; WIEGO, 2020).

Informal workers who work in their homes are least visible. They produce and/or sell goods or services within or near their homes (Chen, Sinha, 2016). They are commonly involved in garment and shoe making or repairing, handcrafting (e.g., embroidering, knitting, carving, carpentry, etc.), textile weaving, cigarette rolling, football or kite making, incense stick rolling, threading flower garlands, food processing, assembling electronics, automobile parts and pharmaceutical products, doing laundry, haircutting (Chen, Sinha, 2016; Bhan et al., 2020; WIEGO, 2020, etc.) and many other works. As it was noted in WIEGO's (2020) report, a part of informal workers working at home are self-employed who sell goods or services directly to markets, while others are sub-contracted and produce work on a piece-rate basis for domestic or global supply chains.

According to the report provided by the OECD Development Centre (2019), informality possesses a strong rural dimension. Based on the OECD Development Centre's (2019) estimations, independently of the area of residence, the agricultural sector presents the highest level of the global informality amounting to 93.6\%. Informal agricultural activities cover cultivation of fruit, vegetables, cereals, floriculture, fisheries, livestock and poultry farming, etc. Reimer (2000) notes that low mobility of the rural population serves as a favourable condition for informal agricultural activities as well as informal exchange. Rural residents can engage in agricultural activities close to their place of residence (e.g. near their homes, in their own and/or neighbouring land, etc.) (Weng, 2015). Close social ties in rural communities also serve this purpose: community members exchange and/or provide each other with resources, share information, experiences, and can even feel obliged to each other (Reimer, 2000). Food delivery from so-called 'safe nets' (relatives, neighbours, familiar farmers, etc.) is particularly beneficial for low-income consumers (Ratner, 2000), and informal exchanges become even more important during the periods of economic and social crises (Reimer, Bollman, 2009).

Finally, the group of informal work in other spaces covers informal work in restaurants and hotels, subcontracted janitors and security guards, casual labourers in the construction sector, piece-rate workers in sweatshops, temporary office helpers or offsite data processors (WIEGO, 2020), workers in the financial sector, personal service sector, entertainment and catering (Shapland, Heyes, 2017).

On balance, numerous forms of informal work can be categorized by the degree of (non)formalization and activity spaces. Despite a wide diversity of occupations, most informal works share such common features as a lack of legal recognition and work without security or social protection. Informal work basically needs to be run through person-to-person contacts to avoid detection and records by the authorities. It is commonly based on personal trust.

\section{METHODOLOGY}

The purpose of the empirical research is to investigate the relationship between unemployment and the shadow economy. The empirical research is based on a quantitative research method - a representative survey. During the survey, the respondents were asked to answer the pre-designed questions. The research sample included the working age (18-65) people who were unemployed at the moment of surveying. The respondents were delivered a survey link online. A total of 1,047 questionnaires were distributed. "Representativeness of a sample is determined by a sample size and a sampling method selected. Probabilistic sampling is based on the probability theory and random selection of a population's elements, but this randomness can be defined and measured: the probability of each element of the population to be included in a sample is known" (Gaižauskaite \& Mikèné, 2014, p. 32). The respondents represented 60 
different municipalities: to ensure the appropriate representativeness of the survey, the number of the respondents from each municipality was selected based on the number of the unemployed in a particular municipality. The survey was conducted over the period November-December 2020.

Demographic characteristics of the respondents (the unemployed) are as follows: the majority of the respondents are aged $36-45(33 \%)$, a slightly smaller share belongs to the $26-35$ age group $(25 \%), 17 \%$ are aged $46-55,14 \%$ - aged $56-65$, and $11 \%$ - aged $18-25.52 \%$ of the survey participants are male, and $48 \%$ female. The majority of the unemployed respondents (59.98\%) have secondary education, $20.63 \%$ - higher education, and $19.20 \%$ - university education. The majority of the respondents are Lithuanian (67\%), $21 \%$ - Russian 21\%, and 12\% - Polish. At the beginning of 2020, Lithuanians made up 85.9, Poles - 5.7, Russians -4.5 , and other nationalities -3.9 percent of the country's total population; thus, Russians and Poles were also included in the survey sample. The majority of the respondents $(61 \%)$ have not had a job for up to 6 months, and only $2 \%$ of the respondents have not had a job for more than a year.

The data were processed by employing SSPS and MS Excel software.

\section{EMPIRICAL RESULTS AND DISCUSSION}

Prior to the analysis of the empirical results, the following hypotheses were formulated:

(H1): The unemployed residing in the border municipalities (Utena, Vilnius, Alytus, Marijampole, Taurage, Klaipeda) are more likely than the unemployed residing in non-border municipalities to disclose their knowledge of the persons who consume or distribute smuggled goods;

(H2): The unemployed residing in smaller municipalities are more likely to justify consumption of smuggled goods than the unemployed residing in larger municipalities;

(H3): More than half of the unemployed have worked in the informal labour market and earned income that was not officially recorded.

The empirical survey was conducted to find out to which extent the unemployed are inclined to participate in informal activities. The respondents were asked if they personally know any people who work without declaring all or a part of their income to the state tax inspectorate and/or social security institutions. The results of the survey revealed that more than half $(56 \%)$ of the respondents know such people (1-2), and more than a third (36\%) know two or more of them (see Figure 1).

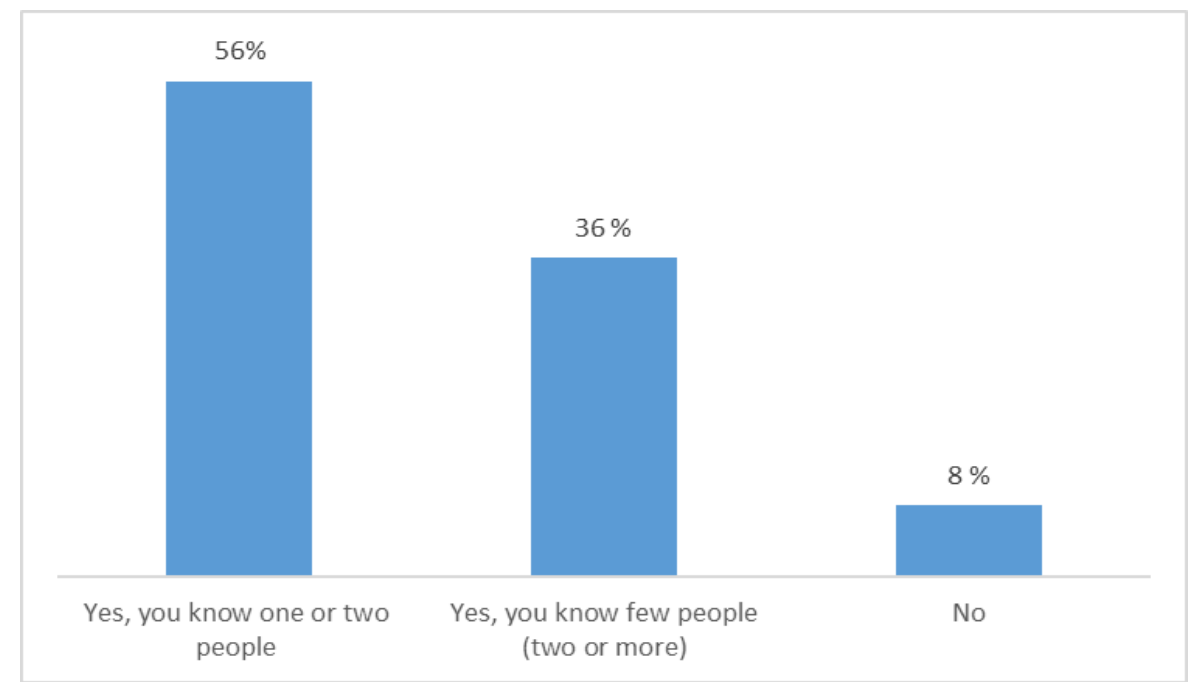

Figure 1. Proportion of the respondents knowing the people working illegally or partially legally, percent

Source: own compilation 
The data also indicate that as many as 88 percent of the respondents know the people who consume or distribute smuggled goods. The survey, however, revealed that more than a third of the respondents $(38 \%)$ do not justify consumption of smuggled goods and participation in smuggling activities.

To explain the nature of unemployment, the respondents were asked to rank the exemplary causes of unemployment in municipalities on a scale from "I strongly agree" to "I strongly disagree". The respondents noted the impact of low wages $(65 \%)$ and the high unemployment rate in regions (rural areas) $(64 \%)$; almost half of the respondents $(49 \%)$ believe that the qualifications they have acquired do not correspond to the supply of jobs (see Figure 2).

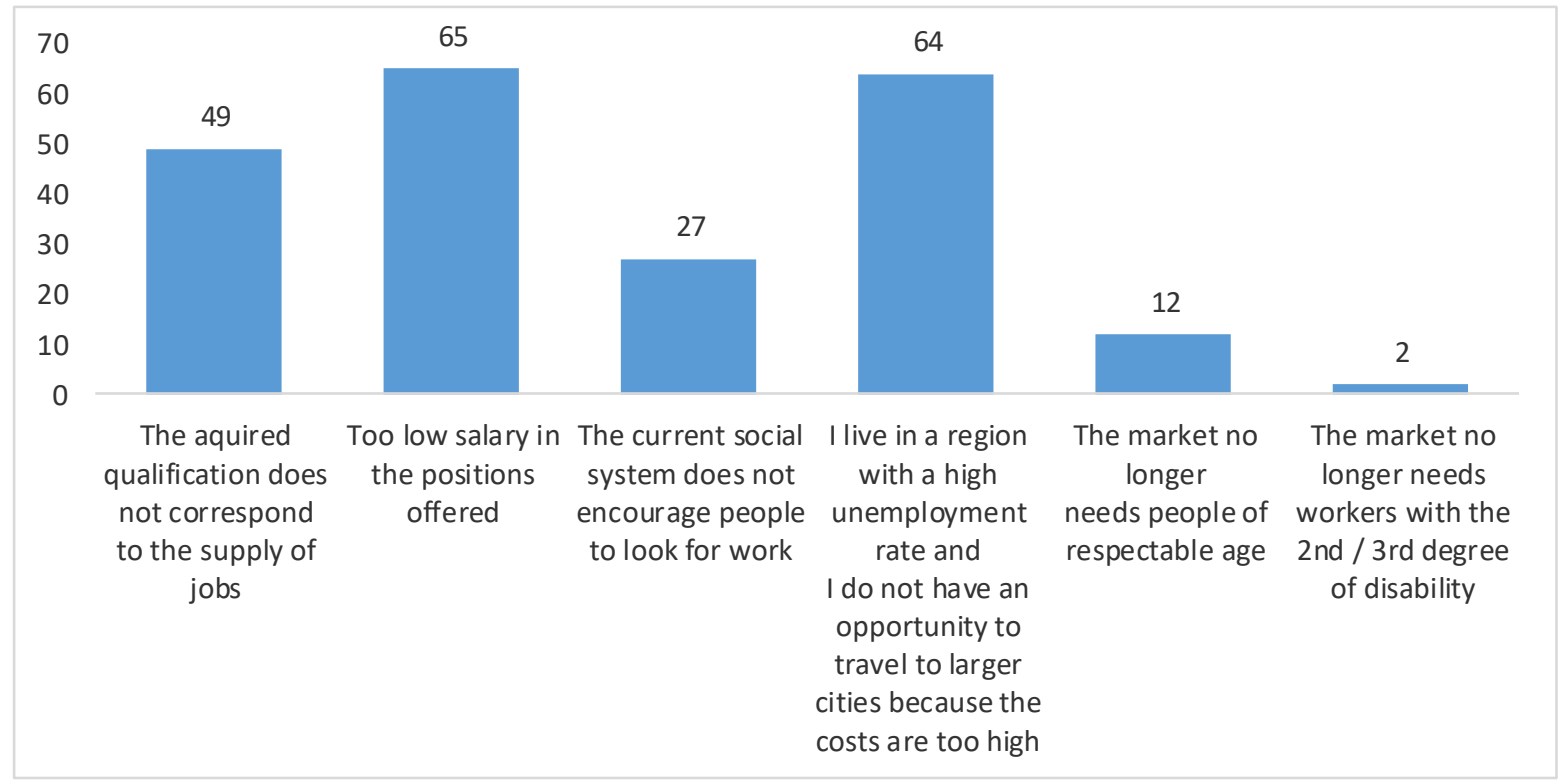

Figure 2. Proportion of the respondents' answers representing the causes of unemployment in municipalities, percent

Source: own compilation

To find out which proportion of the unemployed justify hiding income, the respondents were asked to rank five statements reflecting that income can be hidden by different entities. The respondents needed to indicate if they justify or do not justify hiding income.

The results revealed that the majority of the respondents (43\%) justify hiding income when a private or self-employed person evades taxes by not declaring all or a part of the income, and when a firm hires a private person and pays a part of the wages informally (41\%) (see Figure 3).

The respondents were also asked if over the period of the last 12 months they paid for any goods or services, the income for which was unlikely to be declared (e.g., no invoice or VAT receipt was issued). As many as 70 percent of the respondents confirmed, 24 percent of the respondents denied, and 6 percent of the respondents did not know how to answer the question. 


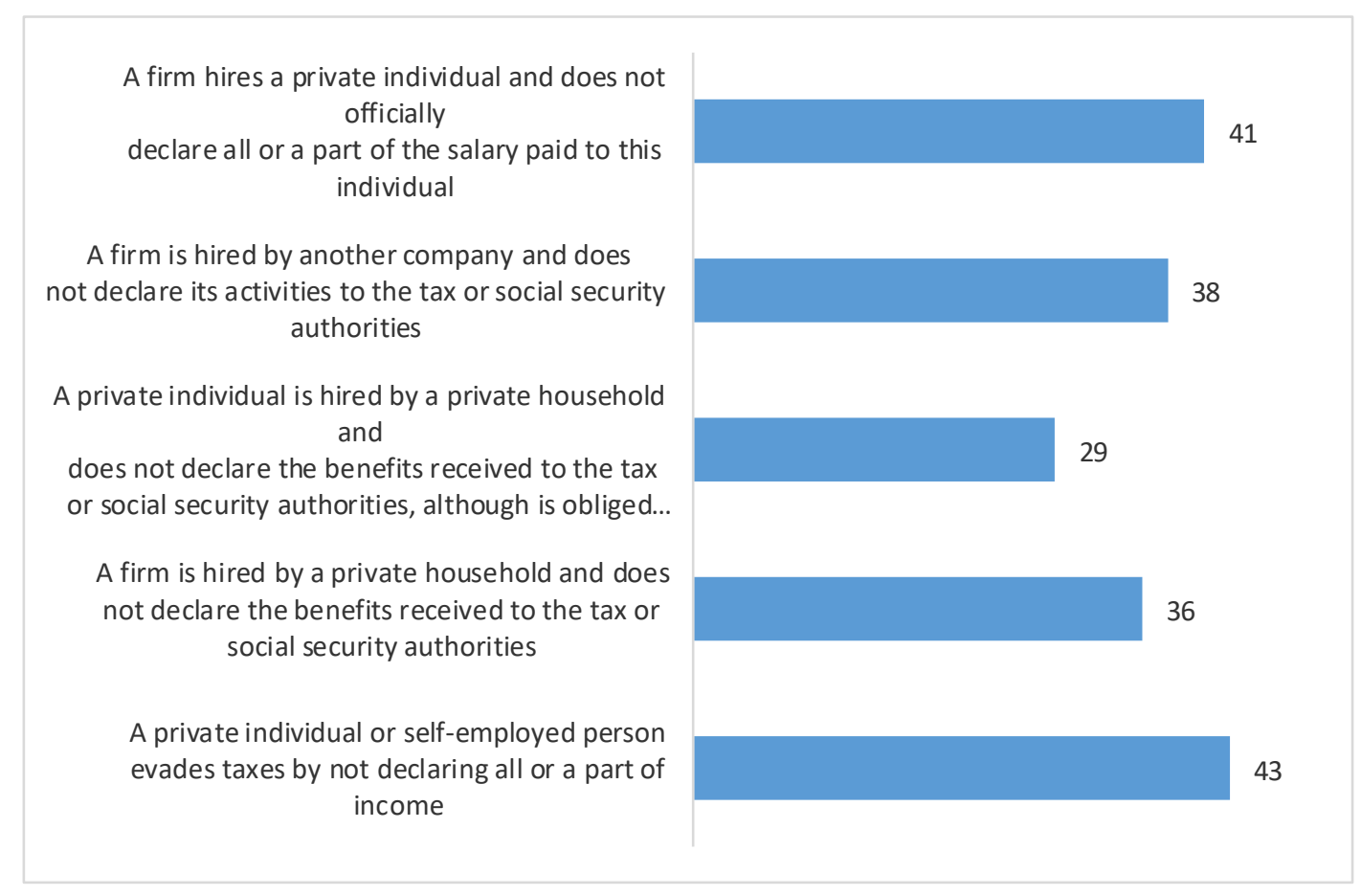

Figure 3. Justification of hiding income, percent

Source: own compilation

The respondents who confirmed the purchase of goods or services even if they felt that the income earned from sales was unlikely to be declared were asked in which sector they encountered this situation. More than a third of the respondents (36\%) indicated the health care sector, less than a fifth $(18 \%)$ hairdressing or other beauty treatments, and $14 \%$ - childcare (see Figure 4).

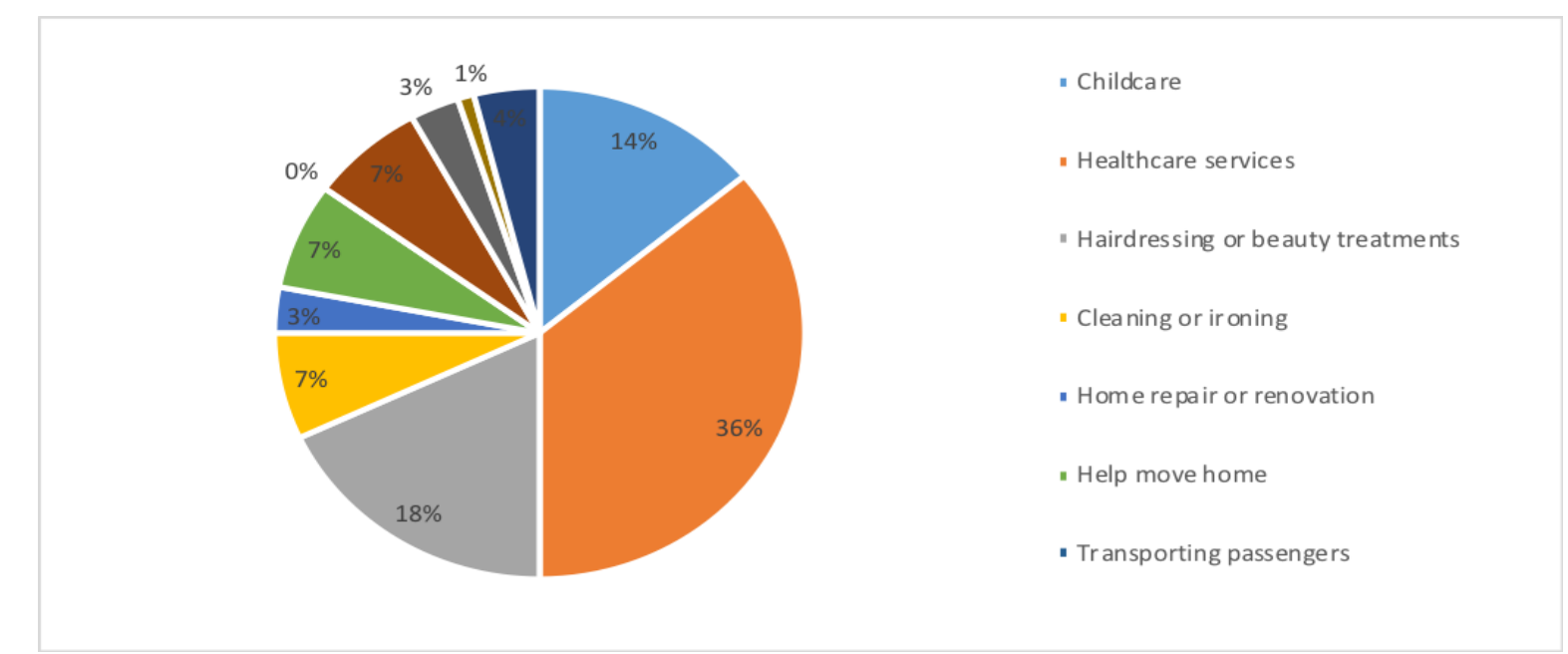

Figure 4. Most common sectors with sales of goods/services without declaring income, percent Source: own compilation

The respondents were asked why they purchased undeclared goods or services rather than the ones from the regular market. The results revealed that the majority of the respondents (as many as 59\%) purchased such services or goods only because of the lower price. Only 3 percent of the respondents used 
such services unconsciously and only then realized that the income earned for such services or goods is unlikely to be declared.

The respondents were also asked if they would accept undeclared wages from an employer. The results revealed that as many as 75 percent of the respondents see no reason why they should not accept undeclared wages from an employer; some of the respondents would accept undeclared wages only in small amounts. It was also found that $68 \%$ of the respondents earned unofficial income over the period of being unemployed.

The respondents who admitted having earned such income were asked to indicate what activities they were involved in. 40 percent of the respondents mentioned housekeeping, 21 percent - construction work, 23 percent worked in agriculture, and 8 percent performed repair works. Finally, the respondents were asked to recommend the measures for reducing unemployment. Most of the unemployed $(45 \%)$ recommend raising the average wage, $36 \%$ of the unemployed offered exempting business start-ups from taxes for one to two years ahead; 19 percent of the respondents expected for reducing the unemployment and other social benefits with consideration of one's health condition.

Two of the three research hypotheses were accepted, one hypothesis was rejected.

(H1): The unemployed residing in the border municipalities (Utena, Vilnius, Alytus, Marijampole, Taurage, Klaipeda) are more likely than the unemployed residing in non-border municipalities to disclose their knowledge of the persons who consume or distribute smuggled goods. 17 municipalities under consideration were border municipalities, 43 - non-border municipalities. H1 is accepted: the unemployed residing in the border municipalities ( 90 percent) are more likely than the unemployed residing in nonborder municipalities ( 87 percent) to disclose their knowledge of the persons who consume or distribute smuggled goods.

(H2): The unemployed residing in smaller municipalities (10) are more likely to justify consumption of smuggled goods than the unemployed residing in larger municipalities (10). Municipalities ranked by their population were extracted from the database of the Centre of Registers. H2 is rejected: the unemployed residing in larger municipalities (67 percent) are more likely to justify consumption of smuggled goods than the unemployed residing in smaller municipalities (62 percent).

(H3): The unemployed registered in smaller municipalities (10) were more likely to earn or seek for income from external short-term orders, for which they were paid in cash (informally), than the unemployed registered in larger municipalities (10). H3 is accepted: a larger proportion of the unemployed registered in smaller municipalities (68 percent) have earned informal income than the proportion of the unemployed registered in larger municipalities (64 percent).

\section{CONCLUSION}

The study revealed that the unemployed are inclined to participate in the shadow labour market. The main causes of informal labour are additional income and justification of informal activities. The unemployed justify hiding income when a private or self-employed person evades taxes by not declaring all or a part of the income, and when a firm hires a private person and pays a part of the salary informally. 92 percent of the unemployed have information about one or more illegally employed persons, and $88 \%$ of the respondents know those who distribute or consume various smuggled goods. The unemployed mostly complain about low wages and the high unemployment rate in their regions. A lack of awareness and justification of informal activities lead to an increase in informal unemployment, which forces consumers to choose undeclared goods and services, mainly because of the lower than the market price. The unemployed are inclined to accept undeclared income from an employer, to purchase undeclared goods and services and consume smuggled products. Consequently, during the period of the COVID-19 
pandemic, unemployment has been closely linked to informal activities because difficult conditions force individuals to survive the emergency, and thus justify the growth of the shadow economy.

\section{ACKNOWLEDGEMENT}

This work was supported by Lithuanian Research Council under Grant [S-GEV-20-3].

\section{REFERENCES}

Altbeker, A., \& Storme, E. (2013). Graduate unemployment in South Africa: A much exaggerated problem. Retrieved from: https://cde.org.za/wp-content/uploads/2018/07/Graduate-unemployment-in-SouthAfrica-A-much-exaggerated-problem-CDE-Insight.pdf

Bhan, G., Surie, A., Horwood, C., Dobson, R., Alfers, L., Portela, A., \& Rollins, N. (2020). Informal work and maternal and child health: a blind spot in public health and research. Bulletin of the World Health Organisation, 98, 219-221. doi: http://dx.doi.org/10.2471/BLT.19.231258

Bukhtiarova, A., Semenog, A., Razinkova, M., Nebaba, N., \& Haber, J. A. (2020). Assessment of financial monitoring efficiency in the banking system of Ukraine. Banks and Bank Systems, 15(1), 98-106. doi:10.21511/bbs.15(1).2020.10

Burger, P., \& Fourie, F. (2019). The unemployed and the formal and informal sectors in South Africa: a macroeconomic analysis. South African Journal of Economic and Management Sciences, 22(1), 1-12. http://dx.doi.org/10.4102/sajems.v22i1.2104

Carrasco Sierra, A., Cobos Flores, M.J., Fuentes Duarte, B., \& Hernández Comi, B.I. (2020). Successful Management System by a Metalworking Mexican Company During Covid-19 Situation. Analysis Through a New Index (Case Study). International Journal of Entrepreneurial Knowledge, 8(2), 42-55. doi: http://dx.doi.org/10.37335/ijek.v8i2.116

CGAP. (2020). Relief for Informal Workers: Falling through the Cracks in COVID-19. Retrieved from: https://www.cgap.org/research/covid-19-briefing/relief-informal-workers-falling-through-cracks-covid-19

Chen, M. A., \& Sinha, S. (2016). Home-based workers and cities. Environment \& Urbanization, 28(2), p. 343-358. doi: $10.1177 / 0956247816649865$.

Cepel, M., Gavurova, B., Dvorsky, J., \& Belas, J. (2020). The impact of the COVID-19 crisis on the perception of business risk in the SME segment. Journal of International Studies, 13(3), 248-263. doi:10.14254/20718330.2020/13-3/16

Dementiev, E.V. (2021). Why Countries Differ Greatly in the Effects of COVID-19. Montenegrin Journal of Economics, 17(4), 55-63. doi: 10.14254/1800-5845/2021.17-4.5

Draskovic, V., Pupavac, J., Delibasic, M., \& Kołtun, L. (2021). Employment in Croatia: Insights into the past and the future. Journal of International Studies, 14(1), 117-128. doi:10.14254/2071-8330.2021/14-1/8

Fialova, K. (2010). Labour institutions and their impact on shadow economies in Europe. Retrieved from: http:/ / citeseerx.ist.psu.edu/viewdoc/download?doi=10.1.1.1013.8440\&rep=rep1\&type $=$ pdf

Fernando, I. N. (2020). Tourism Competitiveness by Shift-Share Analysis to way-forward Destination Management: A case study for Sri Lanka. Journal of Tourism and Services, 21(11), 88-102. https://doi.org/10.29036/jots.v11i20.139

Gadsby, L., \& Samson, R. (2016). Strengthening rural Canada. Why place matters in rural communities. Retrieved from: https://www.decoda.ca/wp-content/uploads/Strengthening-Rural-Canada_Final.pdf

Gaižauskaitè, I., \& Mikelènè, S. (2014). Socialinių tyrimų metodai: apklausa [Social research methods: a survey]. Mykolas Romeris University, p. 285.

Grimm, M., van der Hoeven, R., \& Lay, J. (2011). Unlocking potential: tackling economic, institutional and social constraints of informal entrepreneurship in Sub-Saharan Africa: Main findings and policy conclusions. Retrieved from: https://openknowledge.worldbank.org/bitstream/handle/10986/26878/779250WP0P11510IC00Summary0 OPUBLIC0.pdf?sequence $=1$ \&is Allowed $=\mathrm{y}$ 
Haigner, S., Jenewein, S., Schneider, F., \& Wakolbinger, F. (2011). Dissatisfaction, fear and annoyance: driving forces of informal labor supply and demand. Discussion Paper. Department of Economics, University of Linz, Linz, Austria.

Hendrickx, F. (2019). Informal Employment, New Forms of Work and Enforcement of Labour Rights. Retrieved from: http://regulatingforglobalization.com/2019/10/16/informal-employment-new-forms-of-work-andenforcement-of-labour-rights/

Hvidtfeldt, C., Jensen, B., \& Larsen, C. (2011). Undeclared work and the Danes. University Press of Southern Denmark. English summary in: Rockwool Foundation Research Unit, News, March 2011, Copenhagen, Denmark.

Kolm, A. S., \& Larsen, B. (2016). Informal unemployment and education. IZA Journal of Labor Economics, 5(8), 1-36. doi: 10.1186/s40172-016-0048-6

Krisnaresanti, A., Julialevi, K.O., Naufalin, L.R., \& Dinanti, A. (2020). Analysis of Entrepreneurship Education in Creating New Entrepreneurs. International Journal of Entrepreneurial Knowledge, 8 (2), 67-76. https://doi.org/10.37335/ijek.v8i2.112

Li, Z., Li, J., \& He, B. (2018). Does foreign direct investment enhance or inhibit regional innovation efficiency? Evidence from China. Chinese Management Studies, 12(1), 35-55. doi: 10.1108/CMS-02-2017-0034

Liu, H., Chen, Y., \& Long, H. (2011). Regional diversity of peasant household response to new countryside construction based on field survey in Eastern costal China. Journal of Geographical Sciences, 21(5), 869-881.

Machová, R., Korcsmáros, E., Esseová, M., \& Marča R. (2021). Changing Trends of Shopping Habits and Tourism During the Second Wave of COVID-19 - International Comparison. Journal of Tourism and Services, 22(12), 131-149. https://doi.org/10.29036/jots.v12i22.256

Martinez, L., Short, J. R., \& Estrada, D. (2017). The urban informal economy: street vendors in Cali, Colombia. Cities, 66, 34-43. https://doi.org/10.1016/j.cities.2017.03.010

Medina, M. (2008). The informal recycling sector in developing countries. Retrieved from: https://openknowledge.worldbank.org/bitstream/handle/10986/10586/472210BRI0Box31ing1sectors01PU BLIC1.pdf

Melnyk, M., Syniura-Rostun, N., Lysiak, N., \& Dzyubina, A. (2021a). Business environment of regions in Ukraine: Peculiarities of structural-institutional changes. Problems and Perspectives in Management, 19(1), 456-469. doi:10.21511/ppm.19(1).2021.38

Melnyk, M., Zhabynets, O., Myshchyshyn, I., \& Orlov, V. (2021b). Efficient use of the insurance sector potential adjusted for its shadowing: Case of Ukraine. Insurance Markets and Companies, 12(1), 16-31. doi:10.21511/ins.12(1).2021.02

Navickas, M., Juščius, V., \& Rabe, M. (2020). Shadow economy interconnection with maritime sector development in coastal European countries. Journal of International Studies, 13(3), 309-319. doi:10.14254/2071-8330.2020/13$3 / 20$

National Planning Commission. (2012). National Development Plan 2030. Our future - make it work. Retrieved from:

https://www.poa.gov.za/news/Documents/NPC\%20National\%20Development $\% 20$ Plan\%20Vision $\% 2020$ $30 \% 20$-lo-res.pdf

Nygaard, K., \& Dreyer, M. (2020). Countries provide support to workers in the informal economy. Retrieved from: https://som.yale.edu/blog/countries-provide-support-to-workers-in-the-informal-economy

OECD Development Centre. (2019). Tackling Vulnerability in the Informal Economy. Retrieved from: https://www.oecd-ilibrary.org/docserver/939b7bcd-

en.pdf?expires $=1607792007 \& \mathrm{id}=\mathrm{id} \&$ accname $=$ guest\&checksum $=485 \mathrm{DAF} 507 \mathrm{~F} 57 \mathrm{D} 3297 \mathrm{~A} 3 \mathrm{BD} 1 \mathrm{D} 32183 \mathrm{~B} 44$ 0

Okeleke, U., \& Aponjolosun, M. (2020). A study on the effects of COVID-19 pandemic on Nigerian seafarers. Journal of Sustainable Development of Transport and Logistics, 5(2), 135-142. https://doi.org/10.14254/jsdtl.2020.5-2.12 
Pacolet, J., \& De Wispelaere, F. (2013). The informal economy and the present economic crisis in Europe: Is there an influence?. In Saitta, P., Verhage, A. and Shapland, J. (Eds), Getting by or Getting Rich? The Formal, Informal and Criminal Economy in a Globalised World, 11-28. The Hague: Eleven International Publishing.

Pasternak-Malicka, M., \& Migała-Warchol, A. (2018). Women's professional activity as an element of human capital management in the aspect of non-formal employment. Problems and Perspectives in Management, 16(4), 375-383. doi:10.21511/ppm.16(4).2018.31

Perry, G. E., Maloney, W. F., Arias, O. S., Fajnzylber, P., Mason, A. D., Saavedra-Chanduvi, J., \& Bosch, M. (2007). Informality: exit and exclusion. from: http://siteresources.worldbank.org/INTLAC/Resources/CH0.pdf

Pocius, A. (2015). Šešèlinès ekonomikos ir neoficialaus užimtumo būklès bei tendenciju ìvertinimas Lietuvoje [Evaluation of the shadow economy and informal employment trends in Lithuania]. Lithuanian Journal of Statistics, 54(1), 18-32.

Ramasamy, M., Dhanapal, D., \& Murugesan, P. (2017). Effects of FDI spillover on national productivity: Evidence from panel data analysis using stochastic frontier analysis. International Journal of Emerging Markets, 12(3), 427446. doi: 10.1108/IJoEM-11-2015-0246

Ratner, S. (2000). The informal economy in rural community economic development. Retrieved from: https://www.uky.edu/Ag/AgEcon/pubs/tvaRatner00-03.pdf

Centre of Registers. (2020). Gyventojų skaičius pagal savivaldybes [Population by municipalities]. Retrieved from: https://www.registrucentras.lt/p/853

Reimer, B. (2000). The informal economy in rural Canada. Retrieved from: https://www.researchgate.net/publication/228539278_The_Informal_Economy_in_Rural_Canada

Reimer, B., \& Bollmann, R. D. (2009). Demographic, employment, income, and networks: differential characteristics of rural populations. Journal of Agromedicine, 14(2), 132-141. doi: 10.1080/10599240902845120.

Rogan, M., \& Skinner, C. (2017). The nature of the South African informal sector as reflected in the quarterly labourforce survey, 2008-2014. Retrieved from: https://www.redi3x3.org/sites/default/files/Rogan\%20\%26\%20Skinner\%202017\%20REDI3x3\%20Workin g\%20Paper $\% 2028 \% 20$ Informal $\% 20$ sector $\% 20$ in $\% 20$ SA $\% 20-\% 20$ QLFS $\% 20$ analysis.pdf

Schneider, F. (2011). The shadow economy and shadow economy labor force: What do we (not) know? Retrieved from: http://ftp.iza.org/dp5769.pdf

Schneider, F., Raczkowski, K., \& Mróz, B. (2015). Shadow economy and tax evasion in the EU. Journal of Money Laundering Control, 18(1), 34-51. https://doi.org/10.1108/JMLC-09-2014-0027

Shapland, J., \& Heyes, J. (2017). How close are formal and informal work? International Journal of Sociology and Social Policy, 37(7/8), 374-386. https://doi.org/10.1108/IJSSP-06-2016-0071.

Simionescu, M. (2021). The status of immigrants on Italian labour market in the context of economic decline: Evidence from survey, macroeconomic and big data. Economics, Management and Sustainability, 6(1), 34-48. https://doi.org/10.14254/jems.2021.6-1.3

Tefera, D., \& Delbiso, T. D. (2013). The role of informal sector in alleviating youth unemployment in Hawassa City, Ethiopia. Conference: 59th ISI World Statistics Congress, 25-30 August 2013. Retrieved from: https://www.researchgate.net/publication/282669991_THE_ROLE_OF_INFORMAL_SECTOR_IN_AL LEVIATING_YOUTH_UNEMPLOYMENT_IN_HAWASSA_CITY_ETHIOPIA

Truong, V. D. (2018). Tourism, poverty alleviation, and the informal economy: the street vendors of Hanoi, Vietnam. Tourism Recreation Research, 43(1), 52-67. https://doi.org/10.1080/02508281.2017.1370568

Vasylieva, N. (2021). Food Security in Times of Covid-19: Price Aspects in Ukraine and Neighboring EU Countries. Montenegrin Journal of Economics, 17(3), 21-30. doi: 10.14254/1800-5845/2021.17-3.2

Walsh, J. (2010). Street Vendors and the Dynamics of the Informal Economy: Evidence from Vung Tau, Vietnam. Asian Social Science, 6(11), 159-165. Retrieved from: https://www.researchgate.net/profile/John_Walsh29/publication/47456888_Street_Vendors_and_the_Dyn amics_of_the_Informal_Economy_Evidence_from_Vung_Tau_Vietnam/links/02e7e52e9f8fd8116b000000. pdf 
Weng, X. (2015). The rural informal economy. Understanding drivers and livelihood impacts in agriculture, timber and mining. Retrieved from: http://pubs.iied.org/pdfs/16590IIED.pdf

WIEGO. (2020). Occupational groups in the informal economy. Retrieved from: https://www.wiego.org/informaleconomy/occupational-groups

Williams, C. C. (1996). Informal sector responses to unemployment: an evaluation of the potential of Local Exchange Trading Systems (LETS). Work, Employment \& Society, 10(2), 341-359.

Williams, C. C. (2011). Entrepreneurship, the informal economy and rural communities. Journal of Enterprising Communities: People and Places in the Global Economy, 5(2), 145-157. https://doi.org/10.1108/17506201111131578 